\section{An Evaluation of a Childrens Garden in Developing a Greater Sensitivity of the Environment in Preschool Children}

\author{
Karen Stoelzle M idden ${ }^{1}$ and \\ J essica Chambers²
}

Additional index words. child development lab, curriculum, garden design, outdoor classroom, teachers

Summary. A childrens' garden was designed and installed in a preschool facility to determine if the garden was effective in increasing the children's respect and knowledge of a garden ecosystem. Evaluation of the children's involvement with the garden revealed it to be effectively incorporated into a multidisciplinary curriculum. The children's experience with the garden was a first step in developing environmental sensitivity while providing an opportunity for the staff to experience a garden as an educational tool.

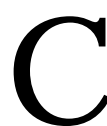

hildren typically will spend a large part of their childhood in elementary schools and daycare centers. Recreational areasgenerally includeplayground equipment, but rarely include natural areas which allow children to usetheir imaginations, create their own games, and

We appreciated the support, enthusiasm, and assistance from the many donors of time and material. We especially appreciate the continued efforts in the garden of Sara Starbuck [ director C hildren's D evelopment $L$ aboratories $(C D L)]$ and $M$ arla DeWerf (master teacher $C D L$ ). The cost of publishing this paper was defrayed in part by the payment of page charges. U nder postal regulations, thispaper thereforemust be hereby marked advertisement solely to indicate this fact.

${ }^{1}$ Associate professor, Plant, Soil and General Agriculture, Southern I IlinoisU niversity, C arbondaleI L 62901.

${ }^{2} \mathrm{G}$ raduate student, Plant, Soil and General Agriculture, Southern Illinois U niversity, Carbondale II 62901. establish their own play patterns (Leccese, 1994). In addition, schools which include gardensand other natural areas are well suited for participatory teaching methods, known to be effectivewith young children ( $M$ atthai and D eaver, 1976). H arvey (1989) found that students who attended schools with developed landscapes demonstrated an increased knowledge of botany and morefavorable attitudes toward the environment. In addition, school grounds that integrated compost bins, container plants, and bird feeders have been shown to enhance a student'slearning experiences( $\mathrm{H}$ arvey, 1989).

Gardens are also a natural classroom to learn about soils, climates, and plant and animal ecosystems (Chawla, 1994). C hildren can definea task, participate in its duties, and bring it to completion when involved in all stages of gardening ( $\mathrm{H}$ art, 1994). Through interaction with plants and nature, children can develop a "respect for the interrelationships among all living things" and develop "knowledge about the issues that is a necessary background for environmental citizenship behavior" (Chawla, 1994; Roger T ory Peterson I nstitute of $\mathrm{N}$ atural H istory, 1990; Stetson, 1990).

\section{Research objectives}

This research had two main objectives. The first was to design and install a working childrens garden as

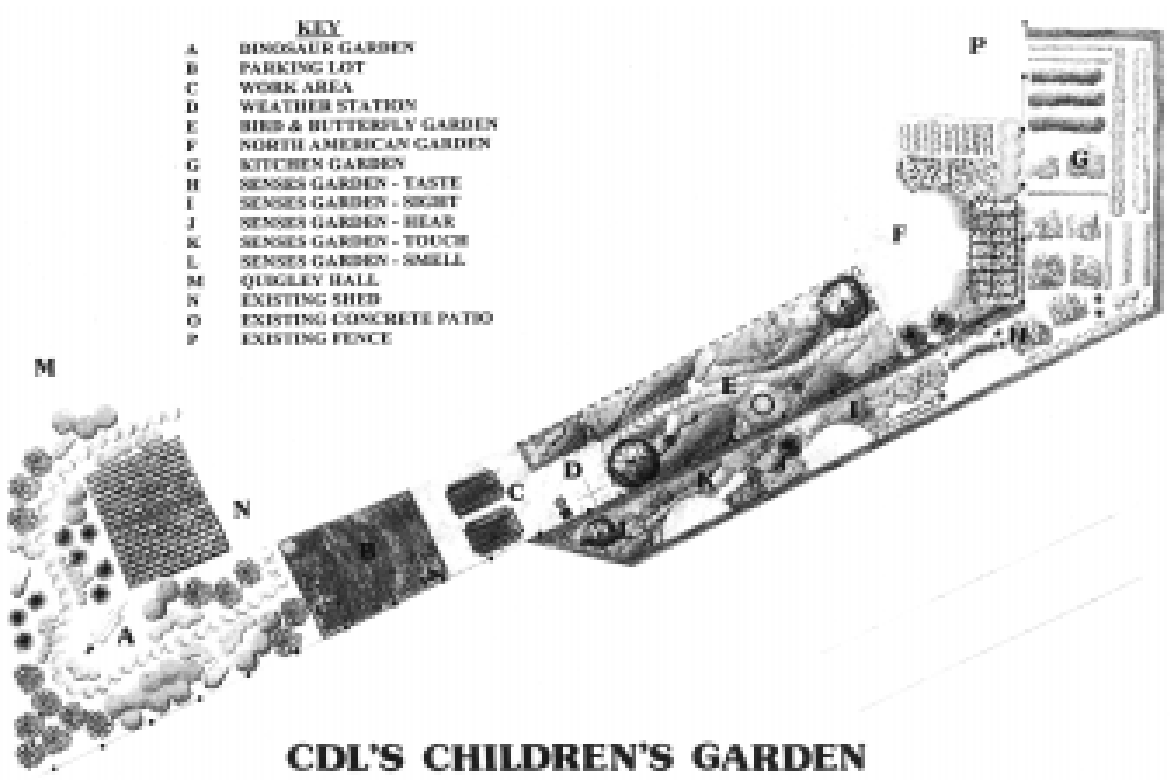

Fig. 1. The childrens garden at the C hildren's D evelopment L aboratory at Southern Illinois U niversity, C arbondale, was comprised of small gardens with themes and spaces for various uses. part of the educational curriculum at the Children's D evelopment Laboratories (CDL) on the campus at Southern Illinois U niversity Carbondale (SI U C). The second was to determine and evaluate a garden' seffectiveness in increasing knowledge of a garden ecosystem and in developing a respect for different life forms.

\section{Methods and materials}

$C D L$ is part of the Curriculum and Instruction $(\mathrm{Cl})$ Department in the College of Education at SIUC. The laboratories provide childcare for children age 6 weeks to 6 years, by teachers comprised of graduate students and practicum students majoring in $\mathrm{Cl}$. The CDL philosophy involves child-direct learning, allowing children to make choicesfrom a variety of planned activities and learning centers throughout the day.

In this study, the design process of Booth and $\mathrm{H}$ iss (1991) was used to develop the garden design. This process involves a site inventory, analysis, conceptual ideas and a refined master plan. The inventory records existing conditions and client information, the analysis utilizes the inventory to develop ideasbased on opportunities and constraints. From theconceptual ideas, a master plan is generated. The CD L garden concept was to develop a childrensgarden for CD L preschoolers (ages 3 to 6 years) as part of their curriculum and play. 
T able 1. Subgardens and their themes.

\begin{tabular}{ll}
\hline $\begin{array}{l}\text { G arden } \\
\text { name }\end{array}$ & F eature \\
\hline Dinosaur & D inosaur sculpture \\
& I guanodon footprint stepping stones \\
& Large, leaved plants \\
Brick parking lot & Space to park tricycles and wagons \\
Work area & Workbench \\
Weather station & Rain gauge \\
& Thermometer \\
Bird and Butterfly & Enclosed by picket fence \\
& Brick path through center \\
& Butterfly house \\
& Bird bath \\
N orth American & Variety of flowering plants and herbs \\
& Trellis house covered by vines \\
Kitchen & Plants native to N orth America \\
Sensory & Vegetables \\
& Fruit \\
& Plants with qualities: \\
& Touch (fuzzy leaves) \\
& Taste (edible) \\
& Hear (make sound) \\
& Smell (fragrant) \\
& Sight (bright) \\
\end{tabular}

Because of space limitations, half of the total garden was installed inside a fenced playground areaand the other half directly adjacent and contiguous but outside the fence.

Six smaller spaces and subgardens with themes comprised the area inside the fence (Fig. 1, Table 1): the dino- saur garden, the parking lot, the work station, the weather station, the bird and butterfly garden, and the $\mathrm{N}$ orth A merican garden. The kitchen garden and the sensory garden were located outside the fence. To provide diversity and interest, elements found in the subgardens reflected each theme, subjectively selected by the researcher and CDL director.

TheCD L preschoolers, staff, parents, SIU C Landscape Design class and others were instrumental in the preparation and installation of the garden as well as construction of its structures. Theinstallation occurred in $\mathrm{M}$ ay 1997.

Four phases were employed to evaluate this research. Phase one involved written observations following interactions with the preschoolers in garden activities. Phase two of the evaluation consisted of two parts: 1 ) individual 10 - to 15 -min interviews and 2) asking each child to draw a picture of a garden. A total of 21 preschoolers chose to participate ( 5 boys, 16 girls), although all of them did not respond to every question. The average child age was 4 years old.

Phase three of the evaluation was a questionnaire completed by eight

T able 2. Q uestions and children's responses related to evaluation of schoolyard garden project at the Children's D evelopment L aboratory at Southern I llinois U niversity.

\begin{tabular}{lcc}
\hline R esponse & R esponse (\%) & Children (no.) \\
\hline Q uestion: When you go outside do you like to go into the gardens? & & 18 \\
Yes & 85.7 & 2 \\
Sometimes & 9.5 & 1 \\
N o & 4.8 & 10 \\
Q uestion: What do you like to do in the gardens? & 33.3 & 4 \\
L ook at plants & 13.3 & 3 \\
Other (study and play) & 10.0 & 3 \\
Pick flowers & 10.0 & 3 \\
Pick vegetables & 10.0 & 2 \\
M aintenance of plants & 6.7 & 2 \\
Smell plants & 6.7 & 1 \\
Pull weeds & 3.3 & 1 \\
Play in trellis & 3.3 & 1 \\
Flower game & 3.3 & 9 \\
N o response & & 7 \\
Q uestion: Which of the gardens do you like to play in the most? & 47 \\
Dinosaur & 37.5 & 1 \\
N orth American & 29.2 & 1 \\
Bird and Butterfly & 16.5 & 1 \\
Sensory & 4.2 & 1 \\
Kitchen & 4.2 & \\
All favorites & 4.2 & 9 \\
N o favorites & 4.2 & 6 \\
Bird and Butterfly & & \\
Dinosaur & 42.9 & 28.6 \\
\hline
\end{tabular}


Table 2. Continued.

\begin{tabular}{|c|c|c|}
\hline Response & R esponse (\%) & Children (no.) \\
\hline $\mathrm{N}$ orth American & 14.3 & 3 \\
\hline Kitchen & 4.8 & 1 \\
\hline All favorites & 4.8 & 1 \\
\hline No favorites & 4.8 & 1 \\
\hline \multicolumn{3}{|l|}{ Q uestion: What do plants need to grow? } \\
\hline Water & 34.7 & 17 \\
\hline Sun & 18.4 & 9 \\
\hline Soil & 12.2 & 6 \\
\hline Seeds & 8.2 & 4 \\
\hline Food & 6.1 & 3 \\
\hline Roots & 4.1 & 2 \\
\hline Fertilizer & 4.1 & 2 \\
\hline Mulch & 4.1 & 2 \\
\hline Other & 4.1 & 2 \\
\hline M aintenance & 2 & 1 \\
\hline $\mathrm{N}$ eeds maintenance & 2 & 1 \\
\hline \multicolumn{3}{|c|}{ Q uestion: What is your favorite thing about plants? } \\
\hline Flowers & 22.7 & 5 \\
\hline Smell & 13.6 & 3 \\
\hline Did not know & 13.6 & 3 \\
\hline Vegetables & 9.1 & 2 \\
\hline Eating plants & 9.1 & 2 \\
\hline Color & 9.1 & 2 \\
\hline All plants are different & 4.5 & 1 \\
\hline Picking plants & 4.5 & 1 \\
\hline Plants give us oxygen & 4.5 & 1 \\
\hline Pulling weeds & 4.5 & 1 \\
\hline Plants with berries & 4.5 & 1 \\
\hline \multicolumn{3}{|l|}{ Question: What do you know about weeds? } \\
\hline Pull weeds & 26.9 & 7 \\
\hline Other (weeds are poisonous) & 19.2 & 5 \\
\hline Did not know & 15.4 & 4 \\
\hline They grow & 15.4 & 3 \\
\hline Weeds are not good for plants & 11.5 & 2 \\
\hline They block the sun from other plants & 3.9 & 1 \\
\hline \multicolumn{3}{|l|}{ Q uestion: What are the parts of a plant? } \\
\hline Leaves & 20.5 & 8 \\
\hline Stem & 15.4 & 6 \\
\hline Did not know & 15.4 & 6 \\
\hline Petals & 10.3 & 4 \\
\hline Flowers & 10.3 & 4 \\
\hline Vegetables & 7.8 & 3 \\
\hline Fruit & 5.1 & 2 \\
\hline Bark & 2.6 & 1 \\
\hline Trunk & 2.6 & 1 \\
\hline Seed & 2.6 & 1 \\
\hline Root & 2.6 & 1 \\
\hline Soil & 2.6 & 1 \\
\hline O ther (dogs smell plants?) & 2.6 & 1 \\
\hline \multicolumn{3}{|c|}{ Q uestion: In the vegetable garden, what did the flowers turn into? } \\
\hline Vegetable & 45.5 & 10 \\
\hline Did not know & 31.8 & 7 \\
\hline Food & 13.6 & 3 \\
\hline Bigger flowers & 4.6 & 1 \\
\hline Color & 4.6 & 1 \\
\hline \multicolumn{3}{|l|}{ Question: $\mathrm{H}$ ow do plants make you feel? } \\
\hline H appy & 72.2 & 15 \\
\hline So-so & 16.7 & 4 \\
\hline Sad & 11.1 & 2 \\
\hline
\end{tabular}

Hortlechnology • A pril-J une $2000 \quad$ 10(2) 

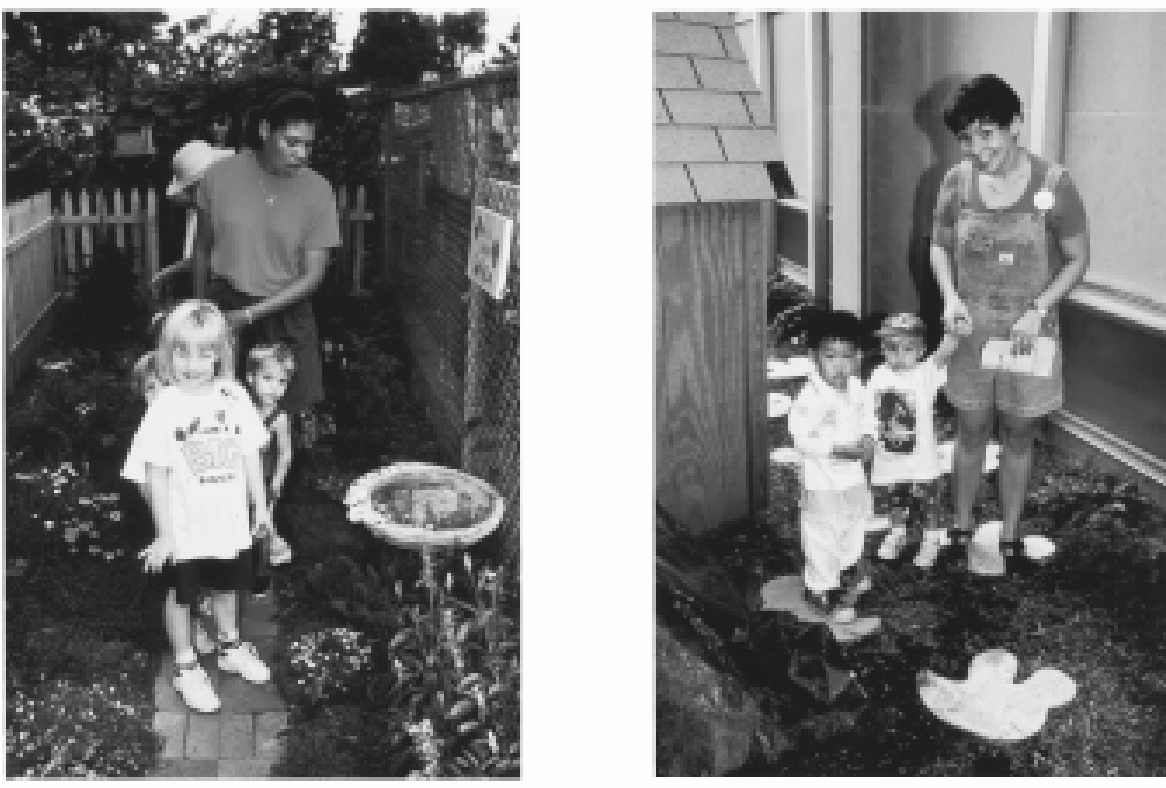

Fig. 2. Paths through the bird and butterfly garden (left) and dinosaur garden (right) allow the children and their visitors to move through the gardens.

teachers. Four teachersworked at CD L in the morning, three in the afternoon and one all day. The fourth phase included agarden journal compiled by the teachers and preschoolers. The journal began with the children planting seeds of a wide variety of plants for their garden at the SI U C H orticulture Research Greenhouse in A pril 1997.

\section{Results and discussion}

In phase one, overall observation was that the children were very enthusiastic about gardening activities and enjoyed the garden. With adult guidance, they sowed seeds, pulled weeds, wheelbarrowed weeds to the compost bin and harvested vegetables. Typically, the children did not work in the garden without ateacher or aresearcher present. H owever, they enjoyed playing in accessible parts of the garden and were anxious to be accompanied by an adult to the garden outside the fence.

There were many indications that the preschoolers were interested in and respected their garden. M ost children were willing to give garden tours to visitors. They discovered insects, birds, and other small inhabitants [ e.g., chipmunks (TamiasstriatusL.)], and enjoyed observing and smelling the flowers. They were careful not to pick unripe vegetables or flowers as per the guidance of adults. O ne day, several girls picked up spent flowers from the ground for their bouquet rather than picking fresh ones. Thechildren quickly learned which plants were weeds and worked to keep them out of the garden. The children were very careful to stay off of the creeping pumpkin (Curcurbita pepo L.) vines with their tricycles.

The second phase revealed that $86 \%$ of the children indicated that they liked going into the garden when they went outside (Table 2). The most popular activity in the garden waslooking at flowers, yet harvesting, maintenance and smelling plants were also favorites (T able 2). The dinosaur garden was the garden the children liked to play in the most (Table 2), but their overall favorite garden was the bird and butterfly garden (Table 2 ). This favoritism may be due to the fact that these gardens were more accessible sincethey were located insidethefence. Additionally, both of these gardens had paths allowing children to play and movethrough the garden (Fig. 2). Theleast favoritegardenswerelocated outside the fence, but the children still enjoyed the activities related to the outside gardens.

Theresponses to questionsfocusing on knowledge indicated that the children learned from their gardening experiences. Collectively, the children answered with 49 correct responses when asked to list the needs of a plant (Table 2). This may be due to the wide range of activitiescentered around plant needs beginning with planting seeds.
Sensory related responses made up $81 \%$ of the children's answers when asked what their favorite things about plants were (Table 2). Most of the activities in the garden involved using one of their senses.

Another frequent activity in the garden was pulling weeds. This may have influenced responses to the question asking the children what they knew about weeds. In total, $27 \%$ knew that weeds needed to be pulled from the garden, another $12 \%$ related that weedswere not good for plants ( $T$ able 2).

Therewere 39 different responses when asked to name parts of a plant. L eaves (20.5\%) was the most frequent response (Table 2). Additionally, 45\% responded correctly that flowers on plants in the vegetable garden turn into vegetables and $13.6 \%$ responded that the flowers turn into food ( $T$ able 2).

To understand how the children felt when they were in the subgardens, they were asked to rate each garden by selecting a happy, neutral (so-so), or sad face (Fig. 3). M ost (average 65\%) of all the subgardens received a happy face rating. Explanations of the sad faces (average 9\%) included a fear of beesand afear of stepping on pumpkin vines. The high positive response indi-

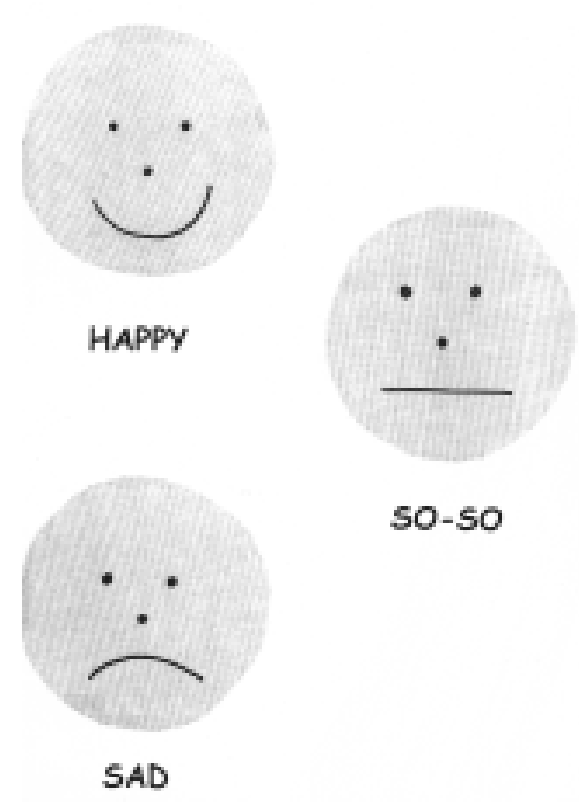

Fig. 3. Children were asked to rate several questions by selecting a face expression best reflecting their opinion. These images were scanned from the original yellow construction paper cut outs. E ach face was laminated and measured about 6 inches $(15 \mathrm{~cm})$ in diameter. 


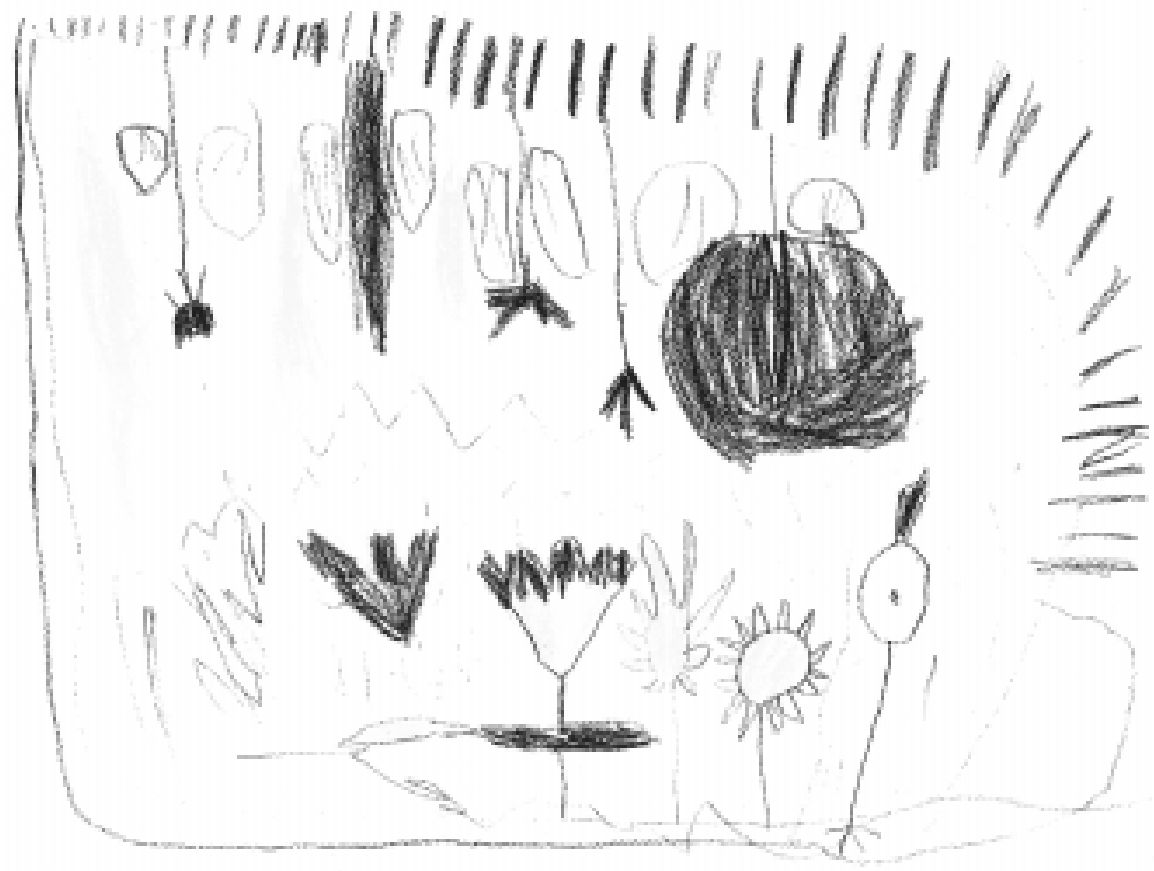

Fig. 4. This garden plan drawn by a 4-year-old female preschooler illustrates several details. The garden area is defined, there are numerous types of flowers, and a weed with roots!

cated that children enjoyed activities in every subgarden, not just their favorites (data not shown). In total, $72 \%$ of the children felt that plants make them happy (Table 2).

Thelast part of theinterview asked children to draw a picture of a garden he/ she would create. The overall content of the drawings consisted of a wide range of items. There were more flowers drawn than vegetables, yet a greater variety of vegetables were drawn. 0 ther items such as bird baths, insects and people were included in somedrawings. 0 nechild drew ascene of flowers and weeds. The roots were drawn on the weed, but not on the flowers (Fig. 4).

Phase three provided contrasting results. Contrary to the opinionsof the children, $50 \%$ of the staff felt that the children's favorite garden was the kitchen garden. The teachers felt that theactivities associated with the kitchen garden gave the children a complete experience, making it their favorite. The bird and butterfly garden was thought to be the children's second favorite by the staff because it generated discussions of such topicsasflower color and insects (Table 3 ).

Again, contradictory, the dinosaur garden wasthought to betheleast favorite $(50 \%)$ of the children ( $\mathrm{T}$ able 3). The teachers felt that there weren't many activities the children could do in that garden. $\mathrm{H}$ owever, the teachers commented that the children weren't visible as they followed the path behind the shed. Therefore, the teachers weren't able to watch the children and sometimes restricted play in that garden.

All eight of the teachers had participated in an activity with the children in the garden. Activities ranged form weeding to measuring plants (Table 3). All eight teachers felt that

T able 3. Q uestions and teacher's responses related to evaluation of schoolyard garden project at the C hildren's D evelopment L aboratory at Southern Illinois U niversity.

\section{Response}

R esponse (\%)

Teachers (no.) $)^{2}$

Q uestion: Which garden do you feel was the children's favorite garden?

Kitchen

Bird and Butterfly

North American

20

Q uestion: Which garden do you feel the children liked the least?

Dinosaur

Sensory

Did not have least favorite

Q uestion: What type of garden activities did you include in your curriculum?

Picking vegetables

Cutting flowers

Planting

Weeding

Watering

Preparing and eating food

L ooking for insects

Journal writing

$M$ easuring plants

L ooking for colors

Reading rain gauge

${ }^{2} \mathrm{~T}$ wo teachers gave two responses. 
the garden was a successful tool for $C D L$ and that the children benefitted in numerous ways from the garden experiences. $\mathrm{H}$ owever, the teachersfelt they needed moreinformation on gardening to feel morecomfortableteaching it to the children.

Phase four, the garden journal entries, revealed that theteachers were very active in using the garden in daily activities and that the children spent free time involved in garden related activities. For example, harvesting and preparing vegetables became a counting game. The children would count green beans (Phaseolus vulgaris L.) after picking, then again after washing and snapping (before eating). They gathered flowers to dry, learning the common flower names as they worked. The teachers remarked frequently that the children learned the names faster than they did. The journal also noted that the children quickly learned to care for the garden; recognizing and pulling a weed and helping to water and mulch. O ther recorded activities included daily temperature, rain fall, scavenger hunts for specific plants, measuring and observing plants, learning "good" and "bad" insects, creating a bird bath and garden related projects inside. The journal contained photographs, comments, stories and drawing, and revealed that teachers incorpo rated garden activities into their curriculum and numerous spontaneousactivitiesoccurred throughout the summer.

\section{Conclusion}

The children's garden was an effective educational tool. The garden provided plant growth and maintenance opportunities for the children and the staff at CD L. C hildren gained knowledge of a garden ecosystem and exhibited some forms of respect for the garden and its inhabitants. T eachers were able to create and incorporate garden experiences as part of their curriculum. Some teachers were apprehensive about working in the garden with children for fear they could not answer technical questions. Yet most questions did not require an in depth knowledge about horticulture or plant biology. In cases where a teacher did not know the answer, researching the topic with the child become a shared activity.

The presence of the garden in conjunction with the garden activities may be the first step in developing environmental sensitivity in the preschoolers and encouraging teachersat $C D L$ to incorporategardensinto their curriculum.

\section{Literature cited}

Booth, N. and J. H iss. 1991. Residential landscape architecture: $\mathrm{D}$ esign process for the private residence. Prentice $\mathrm{H}$ all, Englewood Cliffs, N.J.

Chawla, L. 1994. Gardening as an initiation into environmental action. Amer. H ort. 73(7):6-7.

$\mathrm{H}$ art, R. 1994. Fostering earth stewardship. Amer H ort. 73(7):5-6.

$\mathrm{H}$ arvey, M . 1989. The relationship between children's experiences with vegetation on school grounds and their environmental attitudes. J. Environ. Educ. p. 915.

Leccese, M. 1994. Redefining the idea of play. Landscape Arch. 84(10):72-73.

M atthai, R. and N. Deaver. 1976. Child centered learning. M useum N ews 54(4):15-19.

Roger Tory Peterson Institute of $\mathrm{N}$ atural $\mathrm{H}$ istory. 1990. Bridging early childhood and education. Roger T ory Peterson I nst. N atural H istory, J amestown, N .Y.

Stetson, E. 1990. The big green schoolhouse. Educ L eadership 4(2)20-24. 